\title{
O cyfryzacji badań bistorycznoprawnych. Kilka uwag na marginesie ksiażki Jobna B. Nanna i Morrisa L. Cobena pt. The Yale Law School Guide to Research in American Legal History. New Haven-London: Yale University Press,
} 2018, stron 349

\begin{abstract}
On the Digitization of Historical and Legal Research: A Few Remarks in the Margin of John B. Nann and Morris L. Cohen's Book The Yale Law School Guide to Research in American Legal History. New Haven-London: Yale University Press, 2018, 349 Pages
\end{abstract}

The review deals with a recently published book authored by John B. Nann and Morris L. Cohen and titled "The Yale Law School Guide to Research in American Legal History". The modern, digital inclusive, approach to research in legal history presented by the book's authors, provides a basis for the further comments gathered in the review. The review aims to convince Polish scholars to create a similar tool for young acolytes of legal history.

Keywords: legal history, methodology, digitization, teaching law

Slowa kluczowe: historia prawa, metodologia, cyfryzacja, nauczanie prawa

\section{Wstęp}

We współczesnym polskim dyskursie prowadzonym na polu nauk prawnych coraz częściej zadaje się pytania o metodologię badań. Stawiane są postulaty zajęcia się tym zagadnieniem w sposób pogłębiony. W opinii niektórych przedstawicieli środowiska nauka prawa w Polsce ma na sumieniu liczne zaniedbania na tym polu. Metodologia badań dla 
wielu dyscyplin naukowych stanowi fundament wiedzy przekazywanej nie tylko doktorantom u progu ich kariery naukowej, lecz także studentom stawiającym pierwsze kroki w murach akademii. $\mathrm{W}$ odniesieniu do nauk prawnych taka praktyka niemal w ogóle nie występuje.

Trzeba w tym miejscu zaznaczyć, że problem metodologii to nie tylko kwestia doboru odpowiedniej metody, lecz także narzędzi, które służą jej realizacji. Właśnie na tym tle warto się przyjrzeć wydanej w 2018 r. publikacji autorstwa dwóch wykładowców wydziału prawa Uniwersytetu Yale będących jednocześnie bibliotekarzami uniwersyteckimi - Johna B. Nanna oraz Morrisa L. Cohena - poświęconej tzw. legal research w zakresie badań nad amerykańską historią prawa ${ }^{1}$.

Przed przystąpieniem do zaprezentowania recenzowanej pracy, trzeba na początku przybliżyć pojęcie legal research. Stosuje się je w związku z procesem kształcenia prawników w krajach przynależących do tradycji common law. Zazwyczaj pojęcie to wyjaśniane jest jako proces zadawania pytań i znajdowania odpowiedzi w odniesieniu do konkretnych problemów prawnych. Proces ten utożsamia się tradycyjnie z umiejętnością odnajdywania precedensów, które potencjalnie mogą zostać wykorzystane w argumentacji prezentowanej przed sądem. Ponieważ jednak praktycy prawa działający w obrębie tradycji anglo-amerykańskiej nie wypracowali odmiennych metod stawiania pytań i odnajdywania na nie odpowiedzi od tych wykorzystywanych przez przedstawicieli teorii prawa, legal research odgrywa doniosłą rolę zarówno w procesie kształcenia prawników, jak i w związku z prowadzeniem przez nich badań naukowych. Tym samym nie można zawęzić legal research jedynie do wyszukiwania tzw. „case’ów”. Stanowi ono całościowe instrumentarium prawnika - umiejętność przeszukiwania orzecznictwa, interpretowania prawodawstwa, sporządzania opinii prawnych, pism procesowych, przygotowywania na nie odpowiedzi.

Przeniesienie tego instrumentarium do obszaru nauk historycznoprawnych oznacza uzyskanie tych samych umiejętności, na które wskazano wcześniej, z uwzględnieniem zachodzących w obrębie prawa procesów historycznych (trzeba dodać jednak, iż do pewnego stopnia podział ten jest sztuczny, jako że jedną z cech anglo-amerykańskiej tradycji prawa jest jej historyczność i ciągłość).

\section{Książka}

The Yale Law School Guide to Research in American Legal History jest stosunkowo obszerną publikacją (349 stron), na którą składa się 11 rozdziałów poprzedzonych wprowadzeniem. Pracę kończy niemal trzydziestostronicowy indeks. Układ książki prezentuje się następująco: wprowadzenie, ogólne wskazania bibliograficzne (rozdział 1); prezentacja źródeł i opracowań naukowych przypisanych kolejnym etapom rozwoju prawa amerykańskiego (rozdział 2 - angielskie korzenie prawa amerykańskiego; rozdział 3

1 Omawiana w recenzji publikacja jest owocem kilkudziesięciu lat doświadczeń dydaktycznych na polu legal research przez obu autorów. Zaznaczyć trzeba jednak, że M.L. Cohen zmarł w 2010 r., pozostawiając swoje materiały wykładowe współprowadzącemu zajęcia J.B. Nannowi. Tym samym książka jest swoistym upamiętnieniem dorobku naukowego i dydaktycznego M.L. Cohena. 
- prawo kolonialne; rozdział 4 - kształtowanie się amerykańskiego ustroju; rozdział 5 wczesna republika, tj. od ok. 1790 do końca lat 70. XIX stulecia; rozdział 6 - systematyzacja badań nad historią prawa amerykańskiego, tj. lata 1880-1930; rozdział 7 - państwo administracyjne, tj. lata 1930-2010); materiały archiwalne i źródła praktyki prawa (rozdział 8); źródła dotyczące oddziaływania prawa międzynarodowego oraz tradycji cywilistycznej na prawo amerykańskie (rozdział 9); język prawa i materiały o charakterze biograficznym (rozdział 10); czy wreszcie pozaprawne źródła poznania prawa, np. gazety codzienne, dane statystyczne, archiwa publiczne (rozdział 11).

W ramach każdego rozdziału można wyróżnić kilka charakterystycznych elementów: część merytoryczna; przykład badawczy (Research Example); dalsza literatura (Further Reading); instrumenty, tzn. artykuły, katalogi, zbiory prawodawstwa i orzecznictwa, opisywane w danym rozdziale (Important Sources Mentioned in This Chapter); oraz bazy danych (Databases). W przypadku rozdziałów od drugiego do siódmego dostrzec można ponadto, iż ich część merytoryczna wyraźnie podzielona jest na problematykę orzecznictwa sądowego oraz jego raportowania (w law reports), a także prawodawstwa danego okresu, wraz ze szczegółowymi informacjami na temat jego zbiorów.

Uwagę czytelnika zapoznającego się z treścią omawianej publikacji zwraca przede wszystkim bardzo szerokie potraktowanie cyfrowych narzędzi warsztatu historyka prawa. Dla autorów monografii bazy danych, bazy orzecznictwa czy zdigitalizowane opracowania są równorzędnym źródłem pozyskiwania wiedzy przez współczesnego naukowca, istniejącym obok drukowanych wersji tych samych publikacji. Widać to wyraźnie w strukturze książki. Kwestie „cyfrowe”, które autorzy niektórych brytyjskich i amerykańskich podręczników do legal research ograniczali jeszcze niedawno do jednego rozdziału ${ }^{2}$, w pracy Nanna i Cohena odnaleźć można rozsiane w całej monografii.

Odnotować należy także, iż autorzy nie ograniczyli się jedynie do wymienienia cyfrowych narzędzi. Wskazując na poszczególne bazy danych, dwóch amerykańskich naukowców szeroko wyjaśniło technikę ich działania (metody wyszukiwania danych spośród zgromadzonych zasobów), jak również dzieliło się uwagami, w jaki sposób wyszukiwanie uczynić bardziej efektywnym.

\section{Uwagi}

Z pewnością treść omawianej publikacji nie znajdzie wśród polskich prawników zbyt dużego grona odbiorców. Anglo-amerykańska tradycja prawna nie cieszy się bowiem w Polsce zbyt szerokim zainteresowaniem. Choć, trzeba zauważyć, często bywa przywoływana na marginesie różnorodnych badań komparatystycznych. Nie jest jednak zadaniem tej recenzji ocena wspomnianych odwołań. Podstawowym celem niniejszych rozważań jest zwrócenie uwagi polskiej nauki historii prawa na palącą potrzebę przygotowania podobnego narzędzia jak praca Nanna i Cohena.

2 Zob. np. Elias, Stephen i Susan Levinkind. Legal Research: How to Find and Understand the Law, red. Richard Stim. Berkley: Nolo, 2007, 9, 47-58, 83-86; Knowles, John. Effective Legal Research. London: Sweet \& Maxwell, 2016, 8-24 (z pojedynczymi odniesieniami w dalszej części pracy). 
Dosyć często podnosi się, iż współcześnie obserwowany postęp technologiczny oferuje szerokie możliwości badawcze. Dostęp do baz publikacji naukowych stanowczo ograniczył potrzebę udawania się na zagraniczne kwerendy biblioteczne. Najnowsza literatura przedmiotu jest dostępna $\mathrm{w}$ zasadzie w tym samym momencie dla uczonych pracujących na całym świecie. Digitalizacja publikacji, dawnych traktatów naukowych czy innych dokumentów będących świadectwem procesów legislacyjnych oraz praktyki prawa pozwala na wygodne i rzetelne badanie przeszłości ${ }^{3}$. Dla historyków prawa zajmujących się światem starożytnym nieocenioną pomoc stanowią liczne bazy katalogujące takie źródła, jak tabliczki klinowe, papirusy czy grecki i rzymski materiał epigraficzny. Należy przestrzec jednak przed zbyt pochopnym upraszczaniem tych zjawisk. Skatalogowanie i zdigitalizowanie dawnych dokumentów stanowi dopiero połowę drogi, którą należy przebyć, a która jest niezbędna do osiągnięcia sukcesu badawczego. Materiały te trzeba przede wszystkim odnaleźć, co łączy się często z posiadaniem określonych umiejętności. Oprócz tego szybkość prowadzonych poszukiwań może łatwo przełożyć się na ich jakość. Interesujący nas materiał źródłowy może bowiem być dostępny w formie elektronicznej tylko w części bądź może być rozsiany w różnych bazach danych.

Nie jest również prawdą, iż współczesne młode pokolenie absolwentów prawa posiada rozległą wiedzę na temat korzystania z aktualnych zdobyczy cywilizacji cyfrowej. Dzisiejsi studenci i absolwenci wydziałów prawa należą do osób, które socjolodzy określają mianem „cyfrowych tubylców”. Świat cyfrowy należy do ich codzienności; nie znają świata, w którym przestrzeń cyfrowa by nie istniała ${ }^{4}$. Okazuje się jednak a czas pandemii COVID-19 udowodnił to dobitnie - iż dla wielu owych ,tubylców” ich kontakt ze światem cyfrowym ma jedynie wymiar bierny i konsumencki. Z pewnym zażenowaniem trzeba odnotować, iż wiele $\mathrm{z}$ tych osób ma trudności z prawidłowym edytowaniem tekstu czy korzystaniem z wyszukiwarek internetowych.

Biorąc to pod uwagę, jak również fakt, iż obecnie obowiązujący model szkół doktorskich w pewnym stopniu ograniczył wielowymiarowe kształcenie ich słuchaczy, wyzwania metodologiczne stają się coraz bardziej palące i wymagają systemowych rozwiązań środowiska naukowego. Szeroko rozumiana historia prawa znajduje się w o tyle specyficznej sytuacji, że z jednej strony korzysta z metod stosowanych w naukach dogmatycznych prawa, z drugiej nawiązuje do metod badawczych znanych naukom humanistycznym, w szczególności historii.

Powyższe rozważania mają przede wszystkim na celu zwrócić uwagę czytelników na znaczący postęp cyfryzacji pracy badawczej. Zjawisko to nie może być jednak traktowane z przymrużeniem oka. Stawia ono konkretne wyzwania metodologiczne, a rozpoczynające przygodę naukową młode pokolenie historyków prawa musi uzyskać stosowne wskazówki, jak odnaleźć się w gąszczu informacji. Trzeba bowiem stwierdzić,

3 Najmniej podatna na digitalizację pozostaje tradycja rękopiśmiennicza, które ze względu na swoje rozmiary, różnorodność oraz unikatowość nadal wymaga kwerend archiwalnych. Niemniej także i w tym obszarze dostrzec można pewne próby digitalizacji materiału źródłowego.

4 Zjawisko „cyfrowych tubylców” jest szeroko dyskutowane w literaturze socjologicznej oraz pedagogicznej. W kontekście powyższych rozważań zob. Skibińska, Małgorzata. Czy pokolenie cyfrowe potrzebuje edukacji informacyjnej? W: Edukacja a nowe technologie w kulturze, informacji i komunikacji, red. Małgorzata Skibińska. Toruń: Wydawnictwo Naukowe UMK, 2015, 49-67. 
że powszechny i łatwy dostęp do materiałów badawczych jest równie atrakcyjny jak niebezpieczny. Pośród niebezpieczeństw, które można wymienić bez konieczności prowadzenia bardziej szczegółowej analizy, warto zwrócić uwagę chociażby na wspomniane już zagrożenie pominięcia ważnych dokumentów czy źródeł, których np. w danej bazie danych nie zamieszczono, korzystanie z internetowych wydań źródeł starożytnych czy średniowiecznych traktatów naukowych z pominięciem aparatu krytycznego (najlepszym przykładem tego zjawiska jest odwoływanie się przez romanistów do tekstu Kodyfikacji justyniańskiej zamieszczonego na stronie internetowej Roman Law Library, który m.in. nie dostarcza informacji o proponowanych lekcjach tekstu), bezpodstawne rozbudowywanie tekstów naukowych w oparciu o znajdowanie nowych, często mało znaczących źródeł, które ilościowo nadbudowują narrację, ale nie przekładają się na jakość prowadzonych dociekań. Te wyzwania - unikałbym używania pojęcia problemów - stoją przed współczesną nauką historii prawa na całym świecie. John B. Nann i Morris L. Cohen w ciekawy sposób wyszli naprzeciw tym wyzwaniom. Dali wzorzec, z którego można skorzystać. Nie mam wątpliwości, że polska nauka historii prawa nie może zadawać sobie pytania „czy”, lecz „kiedy” porównywalne opracowanie zostanie przygotowane na rodzimym rynku wydawniczym.

5 https://droitromain.univ-grenoble-alpes.fr/ (data pobrania: 24.02.2021). 